\title{
Boxing for biodiversity: evaluation of an artificiallycreated decaying wood habitat
}

Staffan Carlsson, Karl-Olof Bergman, Nicklas Jansson, Thomas Ranius and Per Milberg

\author{
Linköping University Post Print
}

\section{Tweet}

N.B.: When citing this work, cite the original article.

The original publication is available at www.springerlink.com:

Staffan Carlsson, Karl-Olof Bergman, Nicklas Jansson, Thomas Ranius and Per Milberg, Boxing for biodiversity: evaluation of an artificiallycreated decaying wood habitat, 2016, Biodiversity and Conservation, (25), 2, 393-405.

http://dx.doi.org/10.1007/s10531-016-1057-2

Copyright: Springer Verlag (Germany)

http://www.springerlink.com/?MUD=MP

Postprint available at: Linköping University Electronic Press

http://urn.kb.se/resolve?urn=urn:nbn:se:liu:diva-125192 
MS for Biodiversity \& Conservation

\section{Boxing for biodiversity: evaluation of an artificially created decaying wood habitat}

Staffan Carlsson ${ }^{1}$, Karl-Olof Bergman ${ }^{1}$, Nicklas Jansson ${ }^{1}$, Thomas Ranius ${ }^{2}$, Per Milberg ${ }^{*}$

${ }^{1}$ IFM Biology, Conservation Ecology Group, Linköping University, S-581 83 Linköping, Sweden

${ }^{2}$ Department of Ecology, Swedish University of Agricultural Sciences, Box 7044, 75007 Uppsala, Sweden

*Author for correspondence: permi@ifm.liu.se; +46705173100

4430 words

4 tables

5 figures 


\section{Abstract}

Many saproxylic species are threatened in Europe because of habitat decline. Hollow trees represent an important habitat for saproxylic species. Artificial habitats may need to be created to maintain or increase the amount of habitat due to natural habitat decline. This study investigated the extent to which saproxylic beetles use artificial habitats in wooden boxes. The boxes were placed at various distances $(0-1800 \mathrm{~m})$ from known biodiversity hotspots with hollow oaks and studied over ten years. Boxes were mainly filled with oak saw dust, oak leaves, hay and lucerne flour. In total, 2170 specimens of 91 saproxylic beetle species were sampled in 43 boxes. The abundance of species associated with tree hollows, wood rot and animal nests increased from the fourth to the final year, but species richness declined for all groups. This study shows that wooden boxes can function as saproxylic species habitats. The artificial habitats developed into a more hollow-like environment during the decade long experiment with fewer but more abundant tree hollow specialists.

Keywords: artificial habitats, hollow trees, intervention, saproxylic beetles, succession, wood mould

\section{Introduction}

Hollows form when trees age (Gibbon \& Lindenmayer 2002, Ranius et al. 2009). These hollows are successively colonized by a wide range of taxa, such as birds (Kosinski 2006), mammals (Manning et al. 2013), reptiles (Bryant et al. 2012), beetles (Ranius \& Jansson 2000) and other invertebrates (e.g., mites (Taylor \& Ranius 2014) and pseudoscorpions (Ranius \& Wilander 2000)). Many invertebrates require that hollows contain wood mould (Ranius et al. 2009, Hagen 2015), i.e. residual woody debris that is mixed with insect fragments, dead leaves, bird and mammal remains.

The number of large old trees is declining in many parts of the world (Lindenmayer et al. 2012). Europe has experienced a substantial deciduous forest reduction compared to pre-historic levels (Hannah et al. 1995, Björse \& Bradshaw 1998, Lindbladh \& Bradshaw 1998), greatly affecting the tree species most likely to form hollows (Remm \& Lõhmus 2011). In addition, forestry has reduced the old tree density because trees are often cut before hollows are formed (Eliasson \& Nilsson 2002, Andersson \& Östlund 2004, Lindenmayer et al. 2012). Trees in agricultural landscapes are also declining because they are not useful in agriculture practices (Dubois et al. 
2009). The decrease in hollow trees has caused associated species populations to decline and even become red-listed (Ranius \& Jansson 2000). Management practices have been devised in many countries to promote the formation of hollows in trees (Fritz \& Heilmann-Clausen 2010, Sebek et al. 2013) or create compensatory habitats, such as artificial hollows (Jansson et al. 2009a, Goldingay et al. 2009). Wooden boxes filled with suitable substrates can function as habitats for saproxylic invertebrates (Jansson et al. 2009a, Hilszczański et al. 2014). Although these boxes attract and harbour saproxylic beetles during the first few years of deployment, their durability over time remains unknown. Continued migration over time is often assumed, which may result in species accumulation and late arrivals of certain species (e.g., predators after prey become established; Weslien et al. 2011, Lee et al. 2014). Moreover, a later artificial wood mould decay stage, implying a fungal species composition change, could also cause shifts in the species composition and species richness (Kaila et al. 1994, Økland et al. 1996, Müller et al. 2014).

However, the artificial wood mould is expected to decrease over time in the boxes due to larval consumption and fungal activity, reducing the total habitat volume of the box. This process contrasts that of a natural hollow, in which wood mould is continuously added as the hollow grows. A more thorough understanding and evaluation of these wood boxes is needed to efficiently manage the boxes.

This study investigated the extent to which boxes serve as artificial habitats for saproxylic beetles. More specifically, the study aimed to answer the following questions:

1) How do species richness, abundance and composition change over time?

2) How is species composition affected by the distance from dispersal sources (i.e., sites with hollow oaks)?

3) How is the species composition and richness affected by the original content of the boxes?

These questions were assessed by surveying saproxylic beetle fauna up to ten years after boxes were placed. An earlier study (Jansson et al. 2009a) examined saproxylic beetle fauna in these boxes over the first four years.

\section{Materials and Methods}

\subsection{Field trial}


The box dimensions were $0.70 \mathrm{~m} \times 0.30 \mathrm{~m}$ x $0.30 \mathrm{~m}$, yielding a volume of approximately $60 \mathrm{~L}$. The boxes were constructed of oak, with $25 \mathrm{~mm}$ thick walls and roof and a $50 \mathrm{~mm}$ thick bottom. An $80 \mathrm{~mm}$ diameter hole was cut into the front (Figure 1). The roof could be opened and included a milled cross with four drilled holes (8 $\mathrm{mm}$ in diameter) at the endpoints of the cross, which allowed rain water penetration. The bottom of the box was covered with $50 \mathrm{~mm}$ of clay formed into a bowl shape to retain moisture.

The boxes were filled to 70\% capacity with a mix of oak saw dust (50\%), oak leaves (25\%), hay (10\%), 1 L lucerne flour (2.5\%) (Medicago falcata) and $5 \mathrm{~L}$ water $(12.5 \%)$ at the start of the experiment, emulating the wood mould conditions in hollow trees. In addition, one of four different substrates was added: 1) a dead hen (Gallus domesticus), 2) $1 \mathrm{~L}$ of chicken dung, 3) $1 \mathrm{~L}$ additional lucerne flour plus $1 \mathrm{~L}$ of oat flakes or 4) five potatoes (Table 1). The dead hen and chicken dung were used to mimic the habitat in trunk cavities with bird nests. The lucerne flour and oat flakes increased the protein content and the potatoes created a moist environment. The boxes were suspended on oak trunks, approximately $4 \mathrm{~m}$ from the ground. The boxes were positioned on the shadiest side of each oak to mimic a more stable environment over time.

The study locations included Bjärka-Säby, Brokind and Grebo, which are situated approximately 15-20 km south of Linköping, Sweden (Figure 2). The distance between the locations ranges from $10-20 \mathrm{~km}$. These locations were selected because they are known to harbour species-rich saproxylic invertebrate fauna associated with old hollow oaks (Ranius \& Jansson 2000). Approximately 50-100 hollow oaks exist in the core areas of each of the three locations. Old hollow oaks were absent in one or more directions, which allowed us to study the effect of the distance from a dispersal source.

Boxes were placed in the core area and at two or three surrounding sites with younger oaks. The surrounding sites were between 100 and $1800 \mathrm{~m}$ from the core area (Table 1), but in different directions. This range of distances was used because it is similar to the observed dispersal distances of saproxylic beetles (Ranius 2006). Boxes were spaced at a distance of 10 to $200 \mathrm{~m}$ at each site. Core area boxes were placed on old hollow oaks, while boxes at other sites were placed on younger oaks. Each core area was confirmed as the nearest dispersal source for wood mould dependent species by searching for hollow trees before box placement. No hollow trees that could contain large amounts of wood mould existed around the study sites, including Quercus robur, Fraxinus excelsior, Tilia cordata, Acer platanoides, Aesculus hippocastanum and Ulmus glabra. 
The box experiments lasted for either ten (Brokind, Bjärka Säby) or nine years (Grebo), but had different starting years (2002, 2003 and 2004, respectively). Henceforth, the term "final year" is used for the $10^{\text {th }}$ and $9^{\text {th }}$ years. Five of 48 boxes were broken and discarded during the study period (Table 1).

\subsection{Invertebrate sampling}

Only eclector trap invertebrate sampling data collected during the fourth year and final year were used in this analysis. Sampling was also conducted by placing pitfall traps in the boxes during the second and third years, and the results have been presented elsewhere (Jansson et al. 2009a). An eclector trap means that boxes are covered and sealed with a dark bag made of cloth with a single exit hole (Økland 1996). The hole was located approximately in front of the orifice, and a half transparent white plastic bottle filled with liquid preservatives was placed at the exit hole. The liquid consisted of 50\% propylene glycol, 50\% water and drops of dish soap to eliminate surface tension. The bottles were changed every third week. The sampling began in early spring (March-April) and continued until there no insects emerged (August). In the final year, boxes were taken down permanently and brought to the laboratory for eclector trapping.

Most invertebrates were identified to the species level the authors, but some difficult genera required experts (Stig Lundberg, Arne Ekström, Gunnar Sjödin and Rickard Andersson). All species considered as saproxylic (facultatively or obligatively), according to Dodelin et al. (2008), were used in the present study. The saproxylic beetle species were also classified into ecological 'guilds' based on preferred microhabitat (Ranius \& Jansson 2000), including (i) tree-hollow species (occurs exclusively in rotten wood in hollows), (ii) wood rot species (rotten wood in any part of the trunk), (iii) nest species (nests from birds or other animals in tree hollows), (iv) dry wood species (dead, dry wood in trunks) and (v) fungi species (fruiting bodies of saproxylic fungi). The first three classes were of particular interest because they are more commonly associated with large, hollow oaks than other saproxylic species.

\subsection{Data analyses}

Statistical analyses were conducted using the data from year four and the final year because the same species sampling method was used each year.

A Generalized Linear Models for Multivariate Abundance Data (manyGLM) was used to test the effects of time, distance from the core 
area and substrate type (categorical factor) on the beetle species composition. The model included a negative binomial distribution, unadjusted univariate test and 999 permutations using the mvabund package (Wang et al. 2010). The distance was square root transformed prior to the test and the residual normality was visually checked. Two interactions were analysed in addition to the three main factors (time, distance and substrate type), including time*distance and time*substrate. Hence, manyGLM analysed five factors, resulting in nine estimates per model.

Odds ratios were used to compare the species occurrence odds in the box after four years and the last year. A meta-analytical tool (Comprehensive Metaanalysis 2.0; Borenstein et al. 2005) was used to calculate the weighted averages for species belonging to different guilds, and for those classified as obligate and facultative. A negative effect was observed for boxes directly placed on hollow trees. Therefore, the odds of finding a species in a box on a hollow oak was compared to a box placed some distance away (using boxes placed in the range of 100 to $400 \mathrm{~m}$ from a core area).

\section{Results}

In total, 2170 specimens of 91 saproxylic beetle species were collected from the boxes using eclector traps during the two sampling periods (Table 2).

According to the manyGLM results, there were no statistically significant effects of time $(\mathrm{P}=0.103)$, distance (0.164) from the core area or their interaction (0.536). Species-based models included both increasing and decreasing species with age and distance, but among the 10 species contributing most to the overall model, few displayed a significant response (Table 3). In addition, the substrate effect estimates were not significant (substrate, time*substrate; six P-values ranging from 0.134 to 0.233 ).

Of the 91 saproxylic beetle species sampled in the eclector traps, $62 \%$ exhibited higher odds of occurrence in the fourth year and 31\% higher odds in the final year (Appendix S1). In contrast, the 15 most frequent species were dominant during the last year (Figure 3a). Relatively few species occurred in both years (46\%) and many species were singletons (33\%). The guild-wise odds did not change over time, with the exception of fungi species (i.e. feeding on fruiting bodies of saproxylic fungi) that were most frequent during the fourth year (Figure 3b). Facultative saproxylic species 
were also most frequent during the fourth year $\left(\ln (\mathrm{OR})=-0.545, \mathrm{CI}_{95 \%}\right.$ : $0.963,-0.127)$ in contrast to obligate saproxylic species $(\ln (\mathrm{OR})=-0.545$, $\mathrm{CI}_{95 \%}$ : $\left.-0.455,0.487\right)$.

When contrasting boxes placed on hollow oaks with those placed at some distance from a core area $(100 \mathrm{~m}-400 \mathrm{~m})$, it was apparent from the metaanalysis of all species, that hollow oaks were less preferred $(\ln (\mathrm{OR})=-$ 0.321; CI $_{95 \%}$ : -0.624, -0.018). No differences existed among guilds or when comparing facultative and obligate saproxylic species (data not shown).

\section{Discussion}

This study demonstrates that boxes can function as artificial saproxylic beetle habitats for at least ten years. Furthermore, the distance to real hollow trees affected colonizing species composition.

\subsection{Changes over time}

The species richness decreased between year four and the final year (Table 2). This decrease may be due to a wood mould decrease, as the wood mould volume had decreased by $65 \%$ after ten years (data not shown). All saproxylic beetle guilds experienced species richness declines from the fourth to the final year, but the total abundance of species associated with tree hollows, wood rot and animal nests increased (Table 2). Thus, the beetle assemblage became increasingly dominated by specialized hollow tree species. This dominance in the final year may occur because the artificial wood mould becomes increasingly similar to real wood mould. Saproxylic fauna generally changes with succession, and many species occur in the later decay stages (Kaila et al. 1994, Økland et al. 1996, Lassauce et al. 2011, Müller et al. 2014). In contrast, the facultative saproxylic species generally decreased over time. Consequently, the species composition developed an increasingly higher degree of specialisation to wood mould. Among the noteworthy species using the boxes was Osmoderma eremita (NT, Gärdenfors 2010), of which four specimens were recorded in the last year. $O$. eremita requires old trees with large amounts of wood mould (Ranius et al. 2009). The species is an indicator of high saproxylic beetle species richness (Ranius 2002, Jansson et al. 2009b) and has been proposed as an umbrella species for saproxylic environments.

\subsection{Distance from dispersal sources}


Steady species declines were expected with distance from core areas based on previously observed beetle dispersal limitations in hollow oaks (Ranius \& Hedin 2001, Ranius 2006, Jansson et al. 2009a). However, such a trend was not apparent in the data. This result may suggest that hollow oaks do not constitute the main source habitats of some species. In addition, the boxes were placed on the trunks of hollow oaks and may directly 'compete' for with hollow trees for migrating beetles, while boxes placed at a distance from the hollow oaks might attract a larger proportion of the dispersing beetles (cf Ranius et al. 2010). This assumption was confirmed by comparing the odds of finding a species in a box on a hollow oak in a core area with that of finding a species in a box on a non-hollow oak at some distance away. Hence, a box's benefit may improve if not placed directly on hollow oaks, but on other trees, possibly at a distance from a hollow oak core area.

\subsection{Original box contents}

Neither the different artificial wood mould additives nor the the interactions between time and the additives suggested any influence on composition of the saproxylic beetle species composition (manyGLM). Jansson et al. (2009a) reported differences in the number of specimens between substrate types for some groups after four years, suggesting that potential initial benefits decrease as the decay process continues.

\subsection{Box usage in conservation management}

91 saproxylic beetle species, including a saproxylic environment umbrella species, were detected in this analysis, suggesting that boxes with sawdust are sufficient artificial habitats. With some modification in box design, and a strategy for refilling boxes, they could fulfil their intended role in conservation of saproxylic species. With changes in box design and refilling, the boxes could well be used in conservation management projects. The goals of such projects may be to increase the available habitat or to connect isolated sites. Mature boxes may also be used to translocate saproxylic beetle assemblages.

Five boxes were broken during the ten year period (Table 1). The metallic band holding the box was only attached to the back side of the box and a whole side could come loose. Therefore, the box suspension should be improved so that all sides of the box are held together by the metallic band if used in future conservation management projects. Moreover, some of the boxes began to leak wood mould after the 10 year period when the wood had begun to disintegrate due to larvae consumption, wasp gnawing or 
other reasons. Therefore, the bottom of a box should be covered with a non-consumable substance, such as a plastic sheet. The boxes could also benefit from being larger to obtain a more stable micro-climate. Finally, material that can develop into wood mould must eventually be added to the boxes. Small, annual additions would mimic the dynamics in a tree hollow, but longer intervals can be used for practical and logistical reasons.

\section{Acknowledgements}

We thank Stig Lundberg, Arne Ekström, Gunnar Sjödin and Rickard Andersson for help with beetle identification. We also thank Stiftelsen Oscar och Lili Lamms minne and Eklandskapsfonden i Linköpings kommun for financial support.

\section{References}

Andersson R, Östlund L (2004) Spatial patterns, density changes and implications on biodiversity for old trees in the boreal landscape of northern Sweden. Biological Conservation 118, 443-453.

Björse G, Bradshaw R (1998) 2000 years of forest dynamics in southern Sweden: suggestions for forest management. Forest Ecology and Management 104, 15-26.

Borenstein M, Hedges L, Higgins J, Rothstein H (2005) Comprehensive meta-analysis version 2. Biostat, Englewood, NJ. www.meta-analysis.com

Bryant G, Dundas S, Fleming P, Bennett N (2012) Tree hollows are of conservation importance for a Near- Threatened python species. Journal of Zoology 286, 81-92.

Dodelin B, Ballot P, Stokland J (2008) The saproxylic database checklist of beetles, vers.

8/2008 http://radon.uio.no/WDD/Login.aspx?ReturnUrl=\%2fwdd\%2fDefa ult.aspx Accessed 10th December 2010.

Dubois, G., Vignon, V., Delettre, Y.R., Rantier, Y., Vernon, P., Burel, F. (2009) Factors affecting the occurrence of the the endangered saproxylic beetle Osmoderma eremita (Scopoli, 1763) (Coleoptera: Cetoniidae) in an agricultural landscape. Landscape and Urban Planning. 91, 152-159 
Eliasson P, Nilsson S (2002) 'You should hate young oaks and young noblemen': The environmental history of oaks in eighteenth- and nineteenth- century Sweden. Environmental History 7, 659-677.

Fritz Ö, Heilmann-Clausen J (2010) Rot holes create key microhabitats for epiphytic lichens and bryophytes on beech (Fagus sylvatica). Biological Conservation 143, 1008-1016.

Gärdenfors U, ed. (2010) The 2010 Red List of Swedish species. Swedish Species Information Center, SLU, Uppsala. 592 p.

Gibbons P, Lindenmayer D (2002) Tree hollows and wildlife conservation in Australia. CSIRO Publishing, Collingwood, Australia. 211 pp. ISBN 9780643067059 .

Goldingay RL, Stevens JR (2009) Use of artificial tree hollows by Australian birds and bats. Wildlife Research 36, 81-97.

Hagen S (2015) The significance of tree, site and landscape variables on eight saproxylic beetles in hollow oaks. MSc thesis, Norwegian University of Life Sciences, Department of Ecology \& Natural Resources.

Hannah L, Carr J, Lankerani A (1995) Human disturbance and natural habitat: a biome level analysis of a global data set. Biodiversity \& Conservation 4, 128-155.

Hilszczański J, Jaworski T, Plewa R, Jansson N (2014) Surrogate tree cavities: boxes with artificial substrate can serve as temporary habitat for Osmoderma barnabita (Motsch.) (Coleoptera, Cetoniinae). Journal of Insect Conservation 18, 855-861.

Jansson N, Larsson A, Milberg P, Ranius T (2009a) Boxes mimicking tree hollows can help conservation of saproxylic beetles. Biodiversity and Conservation 18, 3891-3908.

Jansson N, Bergman K-O, Jonsell M, Milberg P (2009b) An indicator system for identification of sites of high conservation value for saproxylic oak (Quercus spp.) beetles in southern Sweden. Journal of Insect Conservation 13, 399-412.

Kaila L, Martikainen P, Punttila P, Yakovlev E (1994) Saproxylic beetles (Coleoptera) on dead birch trunks decayed by different polypore species. Annales Zoologici Fennici 31, 97-107. 
Kosinski, Z., 2006. Factors affecting the occurrence of middle spotted and great spotted woodpeckers in deciduous forests-a case study from Poland. Annales Zoologici Fennici 43, 198-210.

Lassauce A, Paillet Y, Jactel H, Bouget C (2011) Deadwood as a surrogate for forest biodiversity: Meta-analysis of correlations between deadwood volume and species richness of saproxylic organisms. Ecological indicators $11,1027-1039$

Lee SI, Spence JR, Langor DW (2014) Succession of saproxylic beetles associated with decomposition of boreal white spruce logs. Agricultural and Forest Entomology 16, 391-405.

Lindbladh M, Bradshaw R (1998) The origin of present forest composition and pattern in southern Sweden. Journal of biogeography 25, 463-477.

Lindenmayer D, Laurance W, Franklin J (2012) Global decline in large old trees. Science 338, 1305-1306.

Manning A, Gibbons P, Fischer J, Oliver, D, Lindenmayer D (2013) Hollow futures? Tree decline, lag effects and hollow-dependent species. Animal Conservation 16, 395-403.

Milberg P, Bergman K-O, Sancak K, Jansson N (2016) Assemblages of saproxylic beetles on large downed trunks of oak. Ecology \& Evolution 6, in press.

Müller J, Jarzabek-Müller A, Bussler H, Gossner M.M (2014) Hollow beech trees identified as keystone structures for saproxylic beetles by analyses of functional and phylogenetic diversity. Animal Conservation 17, 154-162.

Økland B (1996) A comparison of three methods of trapping saproxylic beetles. European Journal of Entomology 93, 195-209.

Økland B, Bakke A, Hågvar S, Kvamme T (1996) What factors influence the diversity of saproxylic beetles? A multiscaled study from a spruce forest in southern Norway. Biodiversity \& Conservation 5, 75-100

Ranius T (2002) Osmoderma eremita as an indicator of species richness of beetles in tree hollows. Biodiversity and Conservation 11, 931-941.

Ranius T (2006) Measuring the dispersal of saproxylic insects: a key characteristic for their conservation. Population Ecology 48, 177-188. 
Ranius T, Hedin J (2001) The dispersal rate of a beetle, Osmoderma eremita, living in tree hollows. Oecologia 126, 363-370.

Ranius T, Jansson N (2000) The influence of forest regrowth, original canopy cover and tree size on saproxylic beetles associated with old oaks. Biological Conservation 95, 85-94.

Ranius T, Wilander P (2000) Occurrence of Larca lata H.J. Hansen (Pseudoscorpionida: Garypidae) and Allochernes wideri C.L. Koch (Pseudoscorpionida: Chernetidae) in tree hollows in relation to habitat quality and density. Journal of Insect Conservation 4, 23-31.

Ranius T, Niklasson M, Berg N (2009) Development of tree hollows in pedunculate oak (Quercus robur). Forest Ecology and Management 257, 303-310.

Ranius T, Johansson V, Fahrig L (2010) A comparison of patch connectivity measures using data on invertebrates in hollow oaks. Ecography 33: 971-978

Ranius T, Svensson GP, Berg N, Niklasson M, Larsson MC (2009) The successional change of hollow oaks affects their suitability for an inhabiting beetle, Osmoderma eremita. Annales Zoologici Fennici 46, 205216.

Remm J, Lõhmus A (2011) Tree cavities in forests: the broad distribution pattern of a keystone structure for biodiversity. Forest Ecology and Management 262, 579-585.

Sebek P, Altman J, Platek M, Cizek L (2013) Is active management the key to the conservation of saproxylic biodiversity? Pollarding promotes the formation of tree hollows. Plos ONE, 8, 1-6.

Taylor A, Ranius T (2014) Tree hollows harbour a specialised oribatid mite fauna. Journal of Insect Conservation 18, 39-55.

Wang Y, Naumann U, Wright S, Warton D (2010) mvabund: statistical methods for analysing multivariate abundance data. $\mathrm{R}$ package version 3.9.3.

Weslien J, Djupström LB, Schroeder M, Widenfalk O (2011) Long-term priority effects among insects and fungi colonizing decaying wood. Journal of Animal Ecology 80, 1155-1162. 


\section{FIGURE LEGENDS}

Figure 1. A wooden box with a milled cross and holes drilled in the roof. Bowlshaped clay on the bottom of the box and a transparent window with a door to the right.

Figure 2. The locations of the three study sites, south by south-east of Linköping, Sweden (distance in kilometres).

Figure 3. In(Odds ratios) for: (a) 15 of the most frequent saproxylic beetle species found in boxes with artificial wood mould, comparing the fourth year and final year occurrences. Bars indicate 95\% confidence intervals, the zero reference line indicates no difference and positive values indicate that the species was more common during the last year. $O$ and $F$ refer to obligate and facultative saproxylic species. Guild type is also given as rot, nest, hollow, fungi and dry. (b) Weighted average of In(OR) per guild, based on all species classified as belonging to a guild $(N=66)$. "Overall" refers to the outcome when analysing all saproxylic beetle species identified $(\mathrm{N}=91)$. 
Table 1. Number of boxes per distance from sites with hollow oaks and the different added substrates used in the artificial wood mould.

\begin{tabular}{llllll}
\hline $\begin{array}{l}\text { Distances } \\
(\mathrm{m})\end{array}$ & Dead hen & $\begin{array}{l}\text { Chicken } \\
\text { dung }\end{array}$ & $\begin{array}{l}\text { Lucerne } \\
\text { flour and } \\
\text { oat flakes }\end{array}$ & Potatoes & $\begin{array}{l}\text { Total } \\
\text { number of } \\
\text { boxes }\end{array}$ \\
\hline 0 & 3 & 3 & 3 & 3 & 12 \\
100 & $2^{\mathrm{a}}$ & 2 & 2 & $2^{\mathrm{a}}$ & 8 \\
200 & $1^{\mathrm{a}}$ & 1 & 1 & 1 & 4 \\
300 & 1 & 1 & 1 & 1 & 4 \\
400 & 1 & 1 & 1 & 1 & 4 \\
600 & $2^{\mathrm{a}}$ & 2 & 2 & 2 & 8 \\
1800 & 2 & $2^{\mathrm{a}}$ & 2 & 2 & 8 \\
\hline
\end{tabular}

a One of these boxes was broken during the course of the study, and hence excluded from the analyses 
Table 2. A summary of species and specimens found in 43 boxes with artificial wood mould.

\begin{tabular}{|c|c|c|c|}
\hline & $\begin{array}{r}\text { Year four } \\
\text { (SD) }\end{array}$ & $\begin{array}{r}\text { Year ten } \\
\text { (SD) }\end{array}$ & $\begin{array}{r}\text { Both years } \\
\text { (SD) }\end{array}$ \\
\hline Total number of saproxylic beetle species & 75 & 42 & 91 \\
\hline Total number of saproxylic beetle specimens & 1089 & 1081 & 2170 \\
\hline Total number of redlisted saproxylic beetles species & 8 & 5 & 11 \\
\hline Mean number of saproxylic beetle species per box & $5.7(4.3)$ & $5.0(2.8)$ & $10.0(5.1)$ \\
\hline Mean number of saproxylic beetle specimens per box & $25.3(43.2)$ & $25.1(36.0)$ & $50.5(54.7)$ \\
\hline Total number of HWN ${ }^{b}$ species & 47 & 29 & 55 \\
\hline Total number of $\mathrm{HWN}^{\mathrm{b}}$ specimens & 669 & 922 & 1591 \\
\hline Mean number of $\mathrm{HWN}^{\mathrm{b}}$ species per box & $4.1(3.3)$ & $3.5(2.2)$ & $7.0(3.5)$ \\
\hline Mean number of $\mathrm{HWN}^{\mathrm{b}}$ specimens per box & $15.5(18.7)$ & $21.4(31.3)$ & $37.0(36.8)$ \\
\hline Proportion $\mathrm{HWN}^{\mathrm{b}}$ of saproxylic species/specimens & $63 \% / 61 \%$ & $69 \% / 85 \%$ & $60 \% / 73 \%$ \\
\hline
\end{tabular}


Table 3. The top 10 saproxylic species that contributed to the time effect and the distance from the core area (DFCA) effect. Partial results from manyGLM (Generalized Linear Models for Multivariate Abundance Data).

\begin{tabular}{|c|c|c|c|}
\hline & $\begin{array}{l}\text { \% Contribution to time } \\
\text { effect ( } P \text { value; estimate) }\end{array}$ & $\begin{array}{l}\text { \% Contribution to DFCA } \\
\text { effect ( } P \text { value; estimate) }\end{array}$ & $\begin{array}{l}\text { Habitat type } \\
\text { (Saproxylic type)* }\end{array}$ \\
\hline \multicolumn{4}{|l|}{ Top-ranked: time effect } \\
\hline Liocola marmorata & $7.3(0.039 ; 0.47)$ & $1.1(0.775 ; 0.026)$ & hole (O) \\
\hline Scraptia fuscula & $7.2(0.116 ; 0.33)$ & $1.4(0.78 ; 0.016)$ & nest (O) \\
\hline Ctesias serra & $7.0(0.02 ; 1.03)$ & $2.9(0.358 ; 0.083)$ & $\operatorname{rot}(0)$ \\
\hline Hypebaeus flavipes & $5.9(0.063 ; 0.82)$ & $0.7(0.884 ; 0.023)$ & $\operatorname{rot}(0)$ \\
\hline Euplectus mutator & $5.8(0.137 ; 0.31)$ & $2.4(0.617 ; 0.026)$ & (O) \\
\hline Anaspis thoracica & $5.7(0.113 ; 2.07)$ & $4.4(0.215 ;-0.49)$ & (0) \\
\hline Anaspis marginicollis & $4.7(0.156 ; 0.52)$ & $0.5(0.853 ;-0.023)$ & (0) \\
\hline Cryptophagus badius & $4.7(0.055 ; 0.53)$ & $0.7(0.023 ; 0.43)$ & $\operatorname{rot}(0)$ \\
\hline Ptinus rufipes & $4.6(0.27 ; 0.27)$ & $1.7(0.651 ;-0.055)$ & $\operatorname{rot}(0)$ \\
\hline Dasytes cyaneus & $4.6(0.092 ; 0.58)$ & $1.1(0.651 ;-0.062)$ & (O) \\
\hline \multicolumn{4}{|l|}{ Top-ranked: DFCA effect } \\
\hline Ptinus fur ( $(q)$ & $2.8(0.627 ; 0.14)$ & $11.9(0.004 ;-0.32)$ & hole (F) \\
\hline Trox scaber & $0.2(0.042 ;-2.04)$ & $9.0(0.017 ; 0.13)$ & nest $(F)$ \\
\hline Atomaria morio & $3.6(0.076 ; 0.49)$ & $7.4(0.107 ;-1.58)$ & nest $(F)$ \\
\hline Phyllodrepa melanocephala & $0.3(0.126 ;-2.63)$ & $6.3(0.235 ; 0.18)$ & $(F)$ \\
\hline Cryptophagus micaceus & $0.6(0.689 ;-0.064)$ & $6.0(0.274 ; 0.19)$ & nest (O) \\
\hline Prionychus ater & $4(0.485 ; 0.20)$ & $5.2(0.2 ;-0.12)$ & hole (O) \\
\hline Anaspis thoracica & $5.7(0.113 ; 2.07)$ & $4.4(0.215 ;-0.49)$ & (0) \\
\hline Anthrenus museorum & $4.3(0.207 ;-0.25)$ & $4.0(0.167 ;-0.13)$ & nest $(F)$ \\
\hline Dropephylla ioptera & $0(0.376 ;-0.66)$ & $3.9(0.112 ;-0.46)$ & hole (O) \\
\hline Ctesias serra & $7(0.02 ; 1.03)$ & $2.9(0.358 ; 0.083)$ & $\operatorname{rot}(0)$ \\
\hline
\end{tabular}




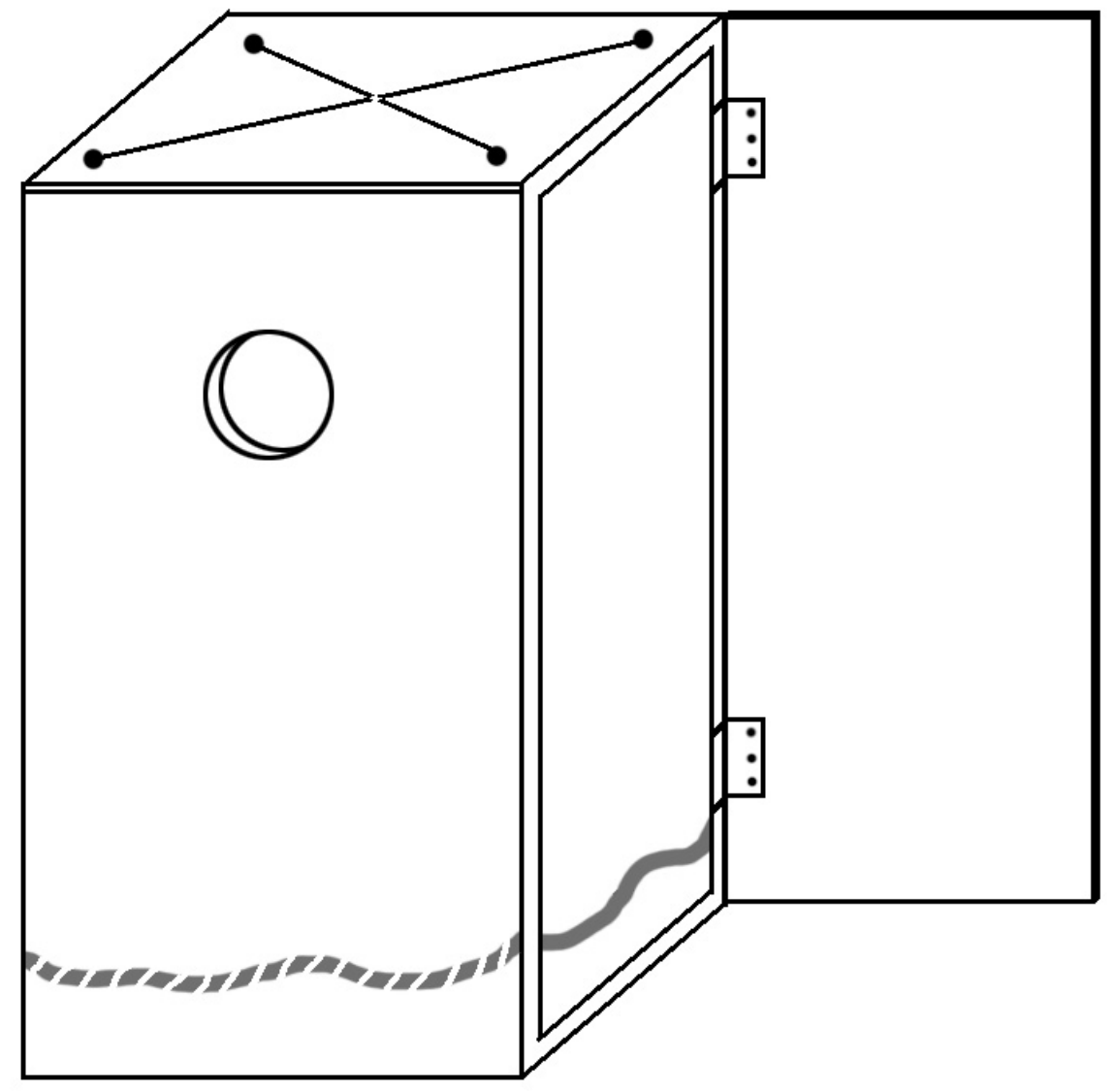

Figure 1. A wooden box with a milled cross and holes drilled in the roof. Bowlshaped clay on the bottom of the box and a transparent window with a door to the right. 


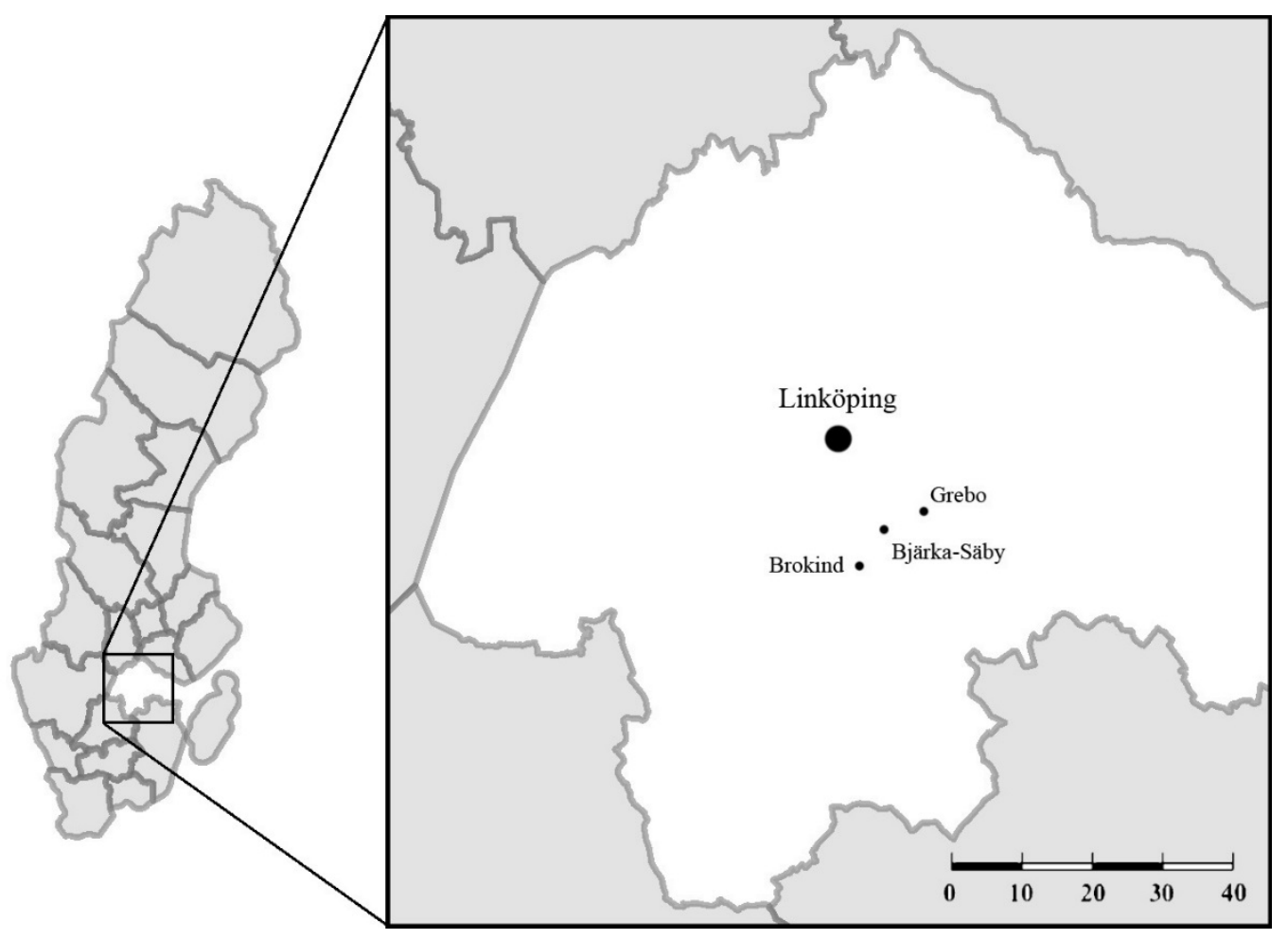

Figure 2. The locations of the three study sites, south by south-east of Linköping, Sweden (distance in kilometres). 

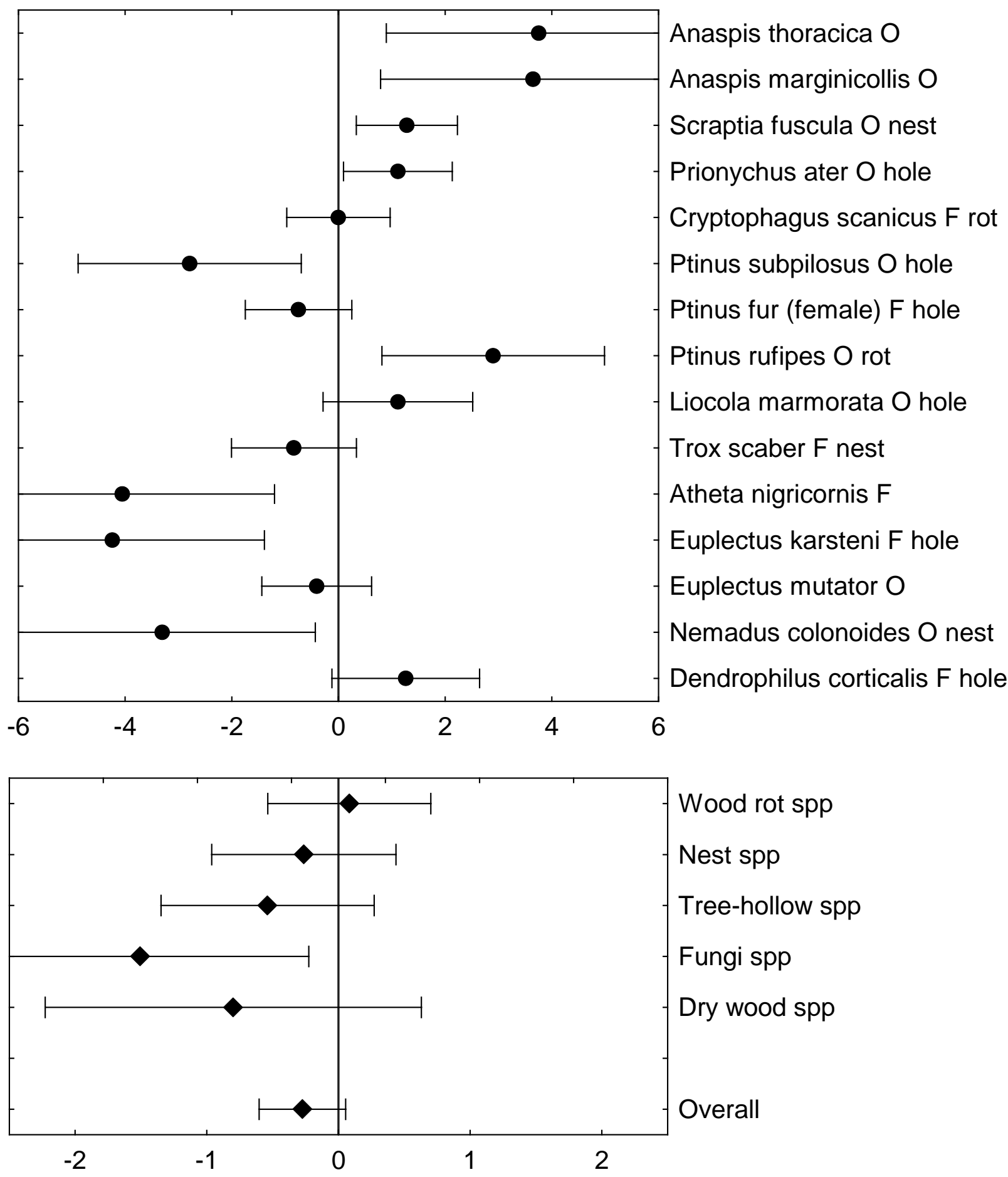

Fourth year

Final year

Figure 3. In(Odds ratios) for: (a) 15 of the most frequent saproxylic beetle species found in boxes with artificial wood mould, comparing the fourth year and final year occurrences. Bars indicate 95\% confidence intervals, the zero reference line indicates no difference and positive values indicate that the species was more common during the last year. $O$ and $F$ refer to obligate and facultative saproxylic species. Guild type is also given as rot, nest, hollow, fungi and dry. (b) Weighted average of In(OR) per guild, based on all species classified as belonging to a guild 
( $N=66)$. "Overall" refers to the outcome when analysing all saproxylic beetle species identified $(N=91)$. 
Appendix S1. Saproxylic beetle species recorded in boxes with artificial wood mould evaluated as an intervention method. In total, 43 boxes were sampled after 4 and 9 or 10 years in the field. $\ln (\mathrm{OR})$ is the $\ln$ (odds ratio) contrasting these two time points; a positive value means an increase over time.

\begin{tabular}{|c|c|c|c|c|c|c|c|}
\hline Species name & $\begin{array}{l}\text { Obligate or } \\
\text { facultative saproxylic } \\
\text { species }\end{array}$ & Guild & $\begin{array}{l}\text { Red listed } \\
2010\end{array}$ & $\operatorname{Ln}(O R)$ & Lower $\mathrm{Cl}_{95 \%}$ & Upper $\mathrm{Cl}_{95 \%}$ & $\begin{array}{l}\text { Number of } \\
\text { occurrences in } \\
\text { boxes (max } 2 * 43 \text { ) }\end{array}$ \\
\hline Plegaderus caesus & 0 & hole & & -1.66 & -4.72 & 1.41 & 2 \\
\hline Gnathoncus & & & & & & & \\
\hline $\begin{array}{l}\text { buyssoni/nannetensis } \\
\text { Dendrophilus }\end{array}$ & $\mathrm{F}$ & nest & & 0.00 & -2.80 & 2.80 & 2 \\
\hline corticalis & $\mathrm{F}$ & hole & & 1.26 & -0.12 & 2.65 & 12 \\
\hline Paromalus flavicornis & $\mathrm{O}$ & rot & & -1.12 & -4.35 & 2.11 & 1 \\
\hline Margarinotus striola & $\mathrm{F}$ & hole & & -1.12 & -4.35 & 2.11 & 1 \\
\hline Nemadus colonoides & 0 & nest & & -3.31 & -6.18 & -0.43 & 10 \\
\hline Stenichnus bicolor & $\mathrm{F}$ & & & -1.12 & -4.35 & 2.11 & 1 \\
\hline Stenichnus godarti & $\mathrm{O}$ & hole & & -1.66 & -4.72 & 1.41 & 2 \\
\hline Scydmaenus hellwigii & $\mathrm{F}$ & nest & & -1.12 & -4.35 & 2.11 & 1 \\
\hline Velleius dilatatus & $\mathrm{F}$ & nest & & -1.12 & -4.35 & 2.11 & 1 \\
\hline Bisnius subuliformis & 0 & nest & & -2.71 & -5.62 & 0.20 & 6 \\
\hline Bibloporus bicolor & 0 & rot & & -1.12 & -4.35 & 2.11 & 1 \\
\hline Gabrius splendidulus & $\mathrm{F}$ & & & -1.12 & -4.35 & 2.11 & 1 \\
\hline Thamiaraea hospita & 0 & & NT & -1.66 & -4.72 & 1.41 & 2 \\
\hline $\begin{array}{l}\text { Quedius brevicornis } \\
\text { Quedius }\end{array}$ & 0 & nest & & -1.66 & -4.72 & 1.41 & 2 \\
\hline mesomelinus & $\mathrm{F}$ & nest & & -0.72 & -3.16 & 1.72 & 3 \\
\hline Quedius cruentus & $\mathrm{F}$ & nest & & -2.02 & -5.01 & 0.98 & 3 \\
\hline Quedius xanthopus & $\mathrm{F}$ & fungi & & -1.12 & -4.35 & 2.11 & 1 \\
\hline Euplectus nanus & $\mathrm{F}$ & hole & & -2.52 & -5.45 & 0.41 & 5 \\
\hline Euplectus mutator & 0 & & & -0.41 & -1.44 & 0.62 & 19 \\
\hline Euplectus karsteni & $\mathrm{F}$ & hole & & -4.24 & -7.09 & -1.39 & 19 \\
\hline Hapalaraea pygmaea & 0 & nest & & 1.66 & -1.41 & 4.72 & 2 \\
\hline
\end{tabular}


Phyllodrepa

melanocephala

Dropephylla ioptera

Hapalaraea nigra

Hapalaraea floralis

Haploglossa villosula

Atheta nigricornis

Atheta crassicornis

Atheta euryptera

Trox scaber

Liocola marmorata

Osmoderma eremita

Ampedus nigrinus

Ampedus nigroflavus

Ampedus tristis

Ampedus pomorum

Ampedus hjorti

Ampedus balteatus

Melanotus

castanipes

Aulonothroscus

brevicollis

Dermestes lardarius

Globicornis nigripes

Megatoma undata

Anthrenus

scrophulariae

Anthrenus museorum

Ctesias serra

Ptinus rufipes

Ptinus fur (female)

Ptinus subpilosus

F

hole

hole

hole

\begin{tabular}{|c|c|c|}
\hline-1.25 & 1.87 & 7 \\
\hline-2.80 & 2.80 & 2 \\
\hline-5.25 & 0.66 & 4 \\
\hline-4.72 & 1.41 & 2 \\
\hline-5.62 & 0.20 & 6 \\
\hline-6.90 & -1.20 & 17 \\
\hline-4.72 & 1.41 & 2 \\
\hline-4.35 & 2.11 & 1 \\
\hline-2.00 & 0.34 & 15 \\
\hline-0.29 & 2.52 & 11 \\
\hline-1.41 & 4.72 & 2 \\
\hline-4.72 & 1.41 & 2 \\
\hline-1.46 & 1.46 & 8 \\
\hline-4.35 & 2.11 & 1 \\
\hline-4.35 & 2.11 & 1 \\
\hline-4.72 & 1.41 & 2 \\
\hline-5.01 & 0.98 & 3 \\
\hline-4.35 & 2.11 & 1 \\
\hline-4.35 & 2.11 & 1 \\
\hline-4.35 & 2.11 & 1 \\
\hline-2.11 & 4.35 & 1 \\
\hline-2.50 & 1.01 & 6 \\
\hline-0.48 & 3.90 & 6 \\
\hline-1.66 & 1.66 & 6 \\
\hline-0.460 & 2.86 & 8 \\
\hline 0.81 & 4.99 & 14 \\
\hline-1.75 & 0.25 & 22 \\
\hline-4.88 & -0.70 & 13 \\
\hline
\end{tabular}


Xestobium

rufovillosum

Gastrallus

immarginatus

Hemicoelus

canaliculatus

Lyctus linearis

Lymexylon navale

Hypebaeus flavipes

Dasytes cyaneus

Trichoceble

memnonia

Rhizophagus

cribratus

Cryptophagus

acutangulus

Cryptophagus badius

Cryptophagus

confusus

Cryptophagus

micaceus

Cryptophagus

quercinus

Cryptophagus

dentatus

Cryptophagus

scanicus

Cryptophagus

reflexus

Cryptophagus

scutellatus

Atomaria morio

Dacne bipustulata

\begin{tabular}{|c|c|c|c|c|c|c|}
\hline $\mathrm{O}$ & dry & & -1.66 & -4.72 & 1.41 & 2 \\
\hline 0 & dry & & -1.12 & -4.35 & 2.11 & 1 \\
\hline 0 & dry & & 1.12 & -2.11 & 4.35 & 1 \\
\hline 0 & dry & VU & -1.12 & -4.35 & 2.11 & 1 \\
\hline 0 & dry & NT & -1.12 & -4.35 & 2.11 & 1 \\
\hline 0 & rot & VU & 0.31 & -1.25 & 1.87 & 7 \\
\hline 0 & & & 3.04 & 0.15 & 5.92 & 8 \\
\hline O & rot & & 1.12 & -2.11 & 4.35 & 1 \\
\hline $\mathrm{O}$ & rot & & -1.12 & -4.35 & 2.11 & 1 \\
\hline $\mathrm{F}$ & & & -1.12 & -4.35 & 2.11 & 1 \\
\hline 0 & rot & & 0.00 & -2.80 & 2.80 & 2 \\
\hline$F$ & hole & & -2.02 & -5.01 & 0.98 & 3 \\
\hline 0 & nest & & 0.00 & -1.46 & 1.46 & 8 \\
\hline 0 & hole & NT & 1.66 & -1.41 & 4.72 & 2 \\
\hline$F$ & fungi & & -2.02 & -5.01 & 0.98 & 3 \\
\hline$F$ & rot & & 0.00 & -0.97 & 0.97 & 22 \\
\hline$F$ & & & -1.12 & -4.35 & 2.11 & 1 \\
\hline$F$ & & & -1.12 & -4.35 & 2.11 & 1 \\
\hline$F$ & nest & & 1.92 & -0.24 & 4.08 & 7 \\
\hline 0 & fungi & & -1.12 & -4.35 & 2.11 & 1 \\
\hline
\end{tabular}


Cerylon histeroides

Latridius minutus

Latridius nidicola

Latridius consimilis

Corticaria serrata

Corticaria longicollis

Corticarina minuta

Corticarina similata

Mycetophagus 4-

guttatus

Diaperis boleti

Tenebrio opacus

Tenebrio molitor

Prionychus ater

Pseudocistela

ceramboides

Mycetochara

humeralis

Mycetochara linearis

Scraptia fuscula

Anaspis marginicollis

Anaspis rufilabris

Anaspis thoracica

Malachius

bipustulatus

rot

$\begin{array}{cc}-1.12 & -4.35 \\ 1.15 & -1.16 \\ 0.72 & -1.72 \\ -1.12 & -4.35 \\ -1.71 & -3.90 \\ 1.12 & -2.11 \\ 1.12 & -2.11 \\ 1.66 & -1.41\end{array}$

2.11

3.45

3.16

2.11

0.48

4.35

4.35

4.72

2.11

$-4.35$

fungi

$-1.12$

$-1.12$

hole

$-1.12$

$-4.35$

$-4.35$

$-0.98$

0.096

1.11

$-2.11$

$-4.72$

$-4.72$

0.34

0.79

$-0.20$

0.90

0.30

3.18

2.11

2.11

5.01

2.13

4.35

1.41

1.41

2.23

6.51

5.62

6.61

6.01

1

1

1

2

1

1

3

23

1

2

2

30

13

6

14

9 